\title{
NATURAL PRODUCT AS CORROSION INHIBITORS IN VARIOUS CORROSIVE MEDIA: A REVIEW
}

\author{
S. Jyothi ${ }^{1, *}$, Y.V. Subba Rao ${ }^{2}$ and P. S. Samuel Ratnakumar ${ }^{3}$ \\ ${ }^{1}$ Department of Science and Humanities, Chemistry Division, \\ Kumaraguru College of Technology, Coimbatore - 641049, Tamil Nadu, India. \\ ${ }^{2}$ Department of physics, BITS-PILANI, Hyderabad campus, \\ Hyderabad - 500078, Telangana state, India. \\ ${ }^{2}$ Instrument division, Ishitv technologies, Yeshwanthpur, \\ Banglore-560022, Karnataka, India. \\ ${ }^{3}$ Department of Mechanical Engineering, Kumaraguru College of Technology, \\ Coimbatore-641049, Tamil Nadu, India. \\ *E-mail: jyothi.sci@kct.ac.in
}

\begin{abstract}
Metals and alloys are pre-eminent and important materials for the construction and fabrications of material. The destruction of metals is a usual and unavoidable process but my opting suitable measures it is controllable. Corrosion is impossible to eliminate but on implementing certain remedies we can control to some extent. Usage of the inhibitors for corrosion is one of the controlling measures used widely. Many corrosion inhibitors are banned due to their environmental hazards and toxicity they create. It leads to making use of naturally occurring extracts of plant materials. Natural corrosion inhibitors are nontoxic and environmentally friendly. This review article provides a detailed account of natural products as corrosion inhibitors in various corrosive media which are making use for the last few decades.
\end{abstract}

Keywords: Corrosion Inhibition, Plant Extracts, Eco- Friendly Inhibitor, Aggressive Media

(c) RASĀYAN. All rights reserved

\section{INTRODUCTION}

The technological advancement in the modern age leads to serious engineering problems called corrosion. Many efforts were made to bring under control the onset and thereafter critical effects of corrosion using many preventive measures. Out of several methods, inhibitors usage is one of the most realistic methods of controlling the corrosion, particularly in aggressive media. In order to reduce the rate of corrosion generally, the inhibitors are used. A variety of compounds both inorganic and organic are used as inhibitors for metals corrosion in different aggressive media. However many researchers ${ }^{1-5}$ reviewed the work on the mechanism of corrosion inhibition and other researchers ${ }^{6,7}$ consolidated the work carried out on the effectiveness of green inhibitors. Some researchers ${ }^{8-10}$ have reviewed the work on utilization of plant sources in corrosion protection. Speller ${ }^{11}$ is the first researcher who identified the inhibition performance of corroded scaled water pipes in the hydrochloric acid medium using organic inhibitor.

A variety of heterocyclic compounds ${ }^{12-15}$ have been accounted as inhibitors for corrosion and still the testing of new synthetic heterocyclic compounds is being persisted. In spite of the potential reports on many inhibitors, most of these inhibitors for corrosion are not only expensive but also nonbiodegradable. This has lead to the search for their replacement. In recent days many rare earth elements ${ }^{16-18}$ and organic compounds ${ }^{19-22}$ have been developed an alternative eco-friendly corrosion inhibitor. During the 1930's the dried seed, stems and leaves extracts of Celandine and other plants were used in $\mathrm{H}_{2} \mathrm{SO}_{4}$ pickling. Proteins from meat and milk were also utilized for reducing the rate of acid corrosion. Yeast, molasses, bran, flour and vegetable oil were also used as an inhibitor for metal corrosion. Starch and tars and oils were also

Rasayan J. Chem., 12(2), 537-544(2019)

http://dx.doi.org/10.31788/RJC.2019.1225000

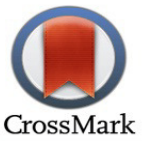


used retard the corrosion in acidic media. Researchers who got first patented for flour, yeast, etc. as corrosion inhibitors ${ }^{23}$ or and also received patent rights for the byproducts obtained from food industries in order to prevent the iron corrosion in acid media ${ }^{24}$.

\section{Plant Extract as Corrosion Inhibitor}

In the 1960's the researchers traced and used phytochemical products as corrosion inhibitors, however, the derivatives of tannins from plants were used to reduce the rate of corrosion on steel, iron, etc. In the year of 1972, El Hosary and team ${ }^{25}$ reported the effect of aqueous extract of Hibiscus subdariffa (Karkade) as an inhibitor for metal corrosion in acidic and alkaline medium. They found that the phytochemical constituents retard the corrosion mitigation process. In 1973, Srivastava and Sanyal explained the influence of nicotine ${ }^{26}$ and caffeine ${ }^{27}$ as an efficient corrosion inhibitor on MS in neutral media. Cabrera and his co workers ${ }^{28}$ established molasses admixed with alkali solution retard the corrosion of steel in $\mathrm{HCl}$. Srivastava and Srivatsava ${ }^{29}$ used tobacco, black pepper, castor oil seeds and lignin as inhibitors for MS corrosion in an acid medium and they showed good efficiency in acidic medium.

Saleh and his co-workers ${ }^{30}$ performed an exhaustive work with Opuntia ficus indica, as a steel corrosion inhibitor. The aqueous extract of the inhibitor is found as a cathodic-type which is get absorbed over the electrode surface in physical nature and follows unimolecular Langmuir adsorption. They were also studied with aloe vera leaves and fruits peels of mango, orange and pomegranate fruits on the corrosion of $\mathrm{MS}, \mathrm{Al}, \mathrm{Zn}$ and $\mathrm{Cu}$ in both $\mathrm{HCl}$ and $\mathrm{H}_{2} \mathrm{SO}_{4}$ acid solutions. They were reported that there is no consistency on the order of efficiency when compared with the metals. It varies for the different metals, whereas mango peels extract performed as the most effective inhibitor for $\mathrm{Al}$ and $\mathrm{Zn}$. Pomegranate fruit-shells shoed the better performance on $\mathrm{Cu}$. In 1985 Fabrizio Zucchi and Ibrahim Hashi Omar ${ }^{31}$ studied the effect of various plants extracts such as Datura stramonmium, Auforpio turkiale sap and Cassia occidentalis seeds, Azadirachta indicia, Poinciana pulcherrima and Papaia as an inhibitor for MS corrosion in $\mathrm{HCl}$ using mass loss and electrochemical studies. They believed that the better performance of corrosion inhibition is mainly due to the phyto constituents formed by the hydrolysis of protein in the plants. Zakvi and Mehta ${ }^{32}$ studied the inhibition on corrosion on steel by Swertia Angustifolia in acid media by PDP and LPR techniques were employed in the potentiostatic mode to study the rate of corrosion exposed to hydrogen-saturated for MS in acid solutions. They were observed that the efficiency of the inhibitor raises up to $0.3 \mathrm{~g} / \mathrm{dm}^{3}$. Similarly, pomegranate alkaloids used as an inhibitor for MS corrosion in $\mathrm{H}_{2} \mathrm{SO}_{4}$ by Aymen Hussein and Singh ${ }^{33}$ using the technique such as galvanostatic polarization and mass loss measurements from lower to elevated temperatures. It was observed that the alkaloids of pomegranate show a lower efficiency at elevated temperatures. Pravinar and his research team ${ }^{34}$ reported that the corrosion inhibition of mild steel and copper in $1 \mathrm{M} \mathrm{HCl}$ solution in the presence of an aqueous extract of eucalyptus leaves. It was found that the inhibition efficiency increases with the increase of the concentration of extract and decrease with increase in temperature.

Sanghvi and co-workers reported the corrosion inhibitive properties of Terminalia belivia, Terminalia chebula, Embilica officianilis ${ }^{35}$, Accacia conicianna and Sapindus trifolianus ${ }^{36}$ for corrosion protection of steel in acid medium. Ebenso and his team performed the inhibitive properties of Carica papaya ${ }^{37}$, Neem ${ }^{38}$ for mild steel corrosion in acidic medium. Natural honey has also stepped into retardation of mild steel corrosion and it was reported by El-Etre ${ }^{39}$. Honey has also been used and studied on copper ${ }^{40}$ and the investigation shows the retardation of the rate of corrosion in the presence of natural honey in saline water.

Aqueous extracts of flowers of Agaricus and hibiscus were used by Minhaj and team ${ }^{41}$ for industrial cooling systems as corrosion preventing additives. The leaves of Eucalyptus ${ }^{42}$ and Pongamia glabra, Annona squamosa ${ }^{43}$ were considered as an inhibitor for corrosion of metal in acid media. The anticorrosion effect of the extracts of Eugenia jambolans ${ }^{44}$ on mild steel in acidic media and Acacia Arabica $^{45}$ were studied by Verma and Mehta. The usage of the mixture of leaves such as anise thyme, coriander, black cumin hibiscus and garden cress retard the steel dissolution in the aggressive medium was authenticated by Khamis and Al-Andis ${ }^{46}$. 
Natural oils play a vital role in green inhibitors from the plant. Rosemary oil, Pennyroyal oil, Jojoba oil, Artemisia oil, Eucalyptus oil, Lavender oil etc. Natural oil extracted from the various plant on corrosion inhibition of various metals on various aggressive environment reported by many researchers and they are given in Table-1.

Table-1: Natural Oil as Inhibitor for MS Corrosion in Acidic Media

\begin{tabular}{|c|c|c|c|}
\hline $\begin{array}{l}\text { Natural Oil and its } \\
\text { Source }\end{array}$ & $\begin{array}{l}\text { Metal/ } \\
\text { Medium }\end{array}$ & Techniques Used & Main Observation \\
\hline $\begin{array}{l}\text { Pennyroyal oil from Mentha } \\
\text { pulegium } \\
47\end{array}$ & $\mathrm{MS}$ in $\mathrm{HCl}$ & $\begin{array}{l}\text { Weight loss, } \\
\text { PDP and EIS }\end{array}$ & $\begin{array}{l}\text { Optimum Concentration : } 2.76 \mathrm{~g} / \mathrm{L} \\
\text { Nature : Cathodic Inhibitor } \\
\text { Adsorption: Chemisorption. }\end{array}$ \\
\hline Jojoba oil ${ }^{48}$ & $\mathrm{MS}$ in $\mathrm{HCl}$ & $\begin{array}{l}\text { Weight loss, and } \\
\text { PDP }\end{array}$ & $\begin{array}{l}\text { Optimum Concentration : } 0.55 \mathrm{~g} / \mathrm{L} \\
\text { Nature : Cathodic Inhibitor } \\
\text { Adsorption: physisorption. }\end{array}$ \\
\hline $\begin{array}{c}\text { Artemisia oil from } \\
\text { Artemisia herba alba }{ }^{49,50}\end{array}$ & $\begin{array}{c}\mathrm{MS} \text { in } 2 \mathrm{M} \\
\mathrm{H}_{3} \mathrm{PO}_{4}\end{array}$ & $\begin{array}{l}\text { Weight loss, } \\
\text { PDP and EIS }\end{array}$ & $\begin{array}{l}\text { Optimum Concentration : } 6 \mathrm{~g} / \mathrm{L} \\
\text { Nature : Cathodic Inhibitor } \\
\text { Adsorption: physisorption. }\end{array}$ \\
\hline $\begin{array}{l}\text { Natural oil from Cassia } \\
\text { auriculata,Cassia siamea- } \\
\text { gonrai, Strychnos nuxvomica } \\
\text { and Crataeva religiaso }^{51}\end{array}$ & $\begin{array}{c}\text { MS and } \\
\text { Copper in } \\
\mathrm{NaCl} \text { and } \mathrm{SO}_{2} \\
\text { environments }\end{array}$ & $\begin{array}{l}\text { Weight loss, } \\
\text { PDP and EIS }\end{array}$ & $\begin{array}{l}\text { Optimum Concentration : } 4 \mathrm{~g} / \mathrm{L} \\
\text { Nature : Mixed Inhibitor }\end{array}$ \\
\hline Rosemary oil ${ }^{52,53}$ & $\begin{array}{c}\mathrm{MS} \text { in } 2 \mathrm{M} \\
\mathrm{H}_{3} \mathrm{PO}_{4}\end{array}$ & $\begin{array}{l}\text { Weight loss, } \\
\text { PDP and EIS }\end{array}$ & $\begin{array}{l}\text { Optimum Concentration : } 10 \mathrm{~g} / \mathrm{L} \\
\text { Nature : Cathodic Inhibitor } \\
\text { Adsorption: physisorption. }\end{array}$ \\
\hline Oil from Eucalyptus ${ }^{54}$ & $\mathrm{MS}$ in $\mathrm{HCl}$ & $\begin{array}{l}\text { Weight loss, and } \\
\text { PDP }\end{array}$ & $\begin{array}{l}\text { Optimum Concentration : } 3 \mathrm{~mL} / \mathrm{L} \\
\text { Nature : Cathodic Inhibitor } \\
\text { Adsorption: chemisorption. }\end{array}$ \\
\hline Artemisia herba alba ${ }^{55}$ & $\begin{array}{c}\text { MS in } 0.5 \mathrm{M} \\
\mathrm{H}_{2} \mathrm{SO}_{4}\end{array}$ & $\begin{array}{l}\text { Weight loss, } \\
\text { PDP and EIS }\end{array}$ & $\begin{array}{l}\text { Optimum Concentration : } 1 \mathrm{~g} / \mathrm{L} \\
\text { Nature : Mixed type Inhibitor } \\
\text { Adsorption: physisorption }\end{array}$ \\
\hline
\end{tabular}

Moreover, the essential oils from various plants such Lavender ${ }^{56}$, Foeniculum Vulgare ${ }^{57}$, Pulicaria mauritanica ${ }^{58}$, Prickly pear seed ${ }^{59}$, Chamomile oil from Chamomilla recutita ${ }^{60}$, Exyngium maritimum $^{61}$, Verben $^{62}$ are having a reasonable corrosion inhibition on metals in aggressive media. The efficiency of the inhibitor improved with the temperature, corresponding to the chemisorption of the inhibitor on the electrode.

Sathyanathan and co-workers extracted inhibitor from Ricimus communis leaves with ethanol and was studied the corrosion protection of mild steel in the acid environment by and found out that the inhibitor behaves as cathodic type ${ }^{63}$. Parikh and Joshi ${ }^{64}$ explained the anticorrosion properties of bitter gourd, garlic and onion for mild steel in $\mathrm{HCl}$ media using Tafel polarization methods and Vicor" method, a computer aided software programme, were used.they found that the Freundlich adsorption equation is applicable and supported the mechanism of inhibition as being chemisorption. Sethuraman and co-workers reported the anticorrosion effect of Andrographis paniculata ${ }^{65}$ and tea wastes ${ }^{66}$.

Bothi raja and his team have executed a sequence of examinations on the corrosion protection of MS using various plant extracts. The efficiency of inhibitor declined with temperature and indicated that follow the physisorption. The research was carried out using Black pepper ${ }^{67}$, Datura metel ${ }^{68}$ and Strychnos nux-vomica ${ }^{69}$ against the deterioration of mild steel in $\mathrm{HCl}$ as well in $\mathrm{H}_{2} \mathrm{SO}_{4}$. Oguzie used the extract of Telforia occidentalis ${ }^{70}$ by weight loss and electrochemical experiments and found that it is highly efficient in acidic media and also studied the effect of the Occium viridis extract ${ }^{71}$ on MS corrosion in pickling bath.

Chauhan and Gunasekaran ${ }^{72}$ executed the corrosion protection of MS in orthophosphoric acid with Zenthoxylum alatum on the corrosion of steel by changing the extract concentrations. They evolved the maximum efficiency of $98 \%$ at $8 \%$ aqueous extract at ambient temperature. Leaves of Nypa fructicans $w_{u r m b}{ }^{73}$ were studied for the corrosion inhibition of mild steel in $\mathrm{HCl}$ media by Orubite and Oforka. The corrosion protection properties of the lupine extract on MS corrosion in aggressive media such as $\mathrm{H}_{2} \mathrm{SO}_{4}$ 
and $\mathrm{HCl}$ was carried out by Abdel-Gaber and his team ${ }^{74}$. The mild steel corrosion inhibitive properties in the presence of seeds and leaves and a combination of both of Phyllanthus amarus ${ }^{75}$ was evolved by Okafor and his team. El-Etre ${ }^{76}$ has established the inhibition potential for carbon steel corrosion in the presence of zallouh root by weight loss and potentiostatic polarization. They believed that the adsorption mechanism obeys Langmuir adsorption. The performance of the inhibitor falls on raising the temperature. Eddy and his co- workers ${ }^{77}$ studied the adsorption properties of Lasianthera Africana for MS corrosion in sulphuric acid by gravimetric, thermometric and gasometric methods. The performance of LA extracts to be a good inhibitor for mild steel corrosion in $\mathrm{H}_{2} \mathrm{SO}_{4}$.

The halides such as $\mathrm{Cl}^{-}$ions synergistically enhance the adsorption corrosion inhibitor, whereas $\mathrm{Br}$ and I retard the adsorption. Synergistic effect of gum exudates from plant material with organic compounds was studied and discussed by many researchers. Jalajaa and her research team studied the synergistic effect between the gum exudates and the substituted piperidone on corrosion inhibition of mild steel in the hydrochloric acid medium by conventional methods ${ }^{79}$. They believed that 3,5-Dimethyl-2,6diphenylpiperidin-4-one alone afford an average inhibition of the corrosion of mild steel and it was found that the inhibition efficiency enhanced synergistically with Moringa oleifera gum exudates.

Afidah and her co-workers extracted inhibitor for MS corrosion from the lignins, of Soda and Kraft from the fruit of palm oil ${ }^{80}$ in neutral media. They inferred that the polarization studies confirmed that both the inhibitors behaved as mixed type. Formation of ferric-lignin compounds on mild steel surface was confirmed by FTIR. Bothraja and his co-workers ${ }^{81-83}$ isolated the alkaloid from Xylopia ferruginea bark and leaves and extracts were tested for mild steel corrosion in a hydrochloric acid medium using EIS and PDP. Adsorption of the molecules over the electrodes was confirmed by SEM and FTIR. Afidha and Kassim worked for the corrosion protection of rusted the inhibitive action of mangrove tannins ${ }^{84}$ on prerusted steel in phosphoric acid medium via electrochemical methods and the development of vegetal tannins ${ }^{85}$ in corrosion protection of iron and steel in acidic medium. The results reflect that the efficiency of the inhibitor of mangrove tannin enhances with the inhibitor concentration. The mechanism of adsorption follows Langmuir isotherm.

Corrosion resistance properties of MS in acidic solution with methanolic extract of Artemisia pallens and its active component as was investigated by Garai ${ }^{86 .}$ The researcher compared the inhibition performance of pure extract and crude. The aqueous extracts of garlic peel ${ }^{87}$ and Thyme leaves ${ }^{88}$ were used as an inhibitor for corrosion on MS in $\mathrm{HCl}$. The results showed that the performance of inhibition increases with the inhibitor concentration. Polarization studies reveal nature as mixed type inhibitor. The active constituents from Artemisia pallens are Arbutin. Arbutin exhibits the inhibition efficiency of 93\% and for the crude methanolic it was $98 \%$ at $30^{\circ} \mathrm{C}$. The inhibitive effect of Punica granatum ${ }^{89}$ extract and important constituents such as ellagic and tannic acid isolated and studied as MS corrosion in $2 \mathrm{M} \mathrm{HCl}$ and $1 \mathrm{M} \mathrm{H}_{2} \mathrm{SO}_{4}$ solutions were performed..

Though many researchers have reported on the use of corrosion inhibitors extracted from natural products and isolation and identification of the active constituents are responsible on the protection of metals and alloys from corrosion and as well as the mechanistic approaches have seldom been discussed. But some of the researchers reported the alkaloid extracts and isolated compounds and their corrosion inhibition on metal in acidic media. isoreserpiline is the major alkaloid extracted from the bark and leaves of Ochrosia oppositifolia $^{90}$, and were reported as potential inhibitors for mild steel corrosion in hydrochloric acid medium. The inhibition properties of these phytoconstituents were studied using PDP, EIS, SEM, FTIR and molecular modeling techniques. Similarly, a marine alga Caulerpa racemosa ${ }^{91}$ was tested as a potential corrosion retarding agent on mild steel in $1 \mathrm{M} \mathrm{HCl}$ solution by weight loss and electrochemical methods.

The important phytoconstituent such as a bis-indole and caulerpin alkaloids were isolated and characterized by UV spectroscopy, NMR and FTIR. The anticorrosion activities of the alkaloids were investigated by using polarization, impedance, and AFM. They have established the anticorrosion potential of Caulerpa and correlated it due to the presence of caulerpin.

\section{Statistical and Theoretical Approach to Corrosion Inhibition}

Simulation is an important analytical computational means for composite scientific and engineering issues. Simulation turns into standard statistical methods where the output can be analyzed using. 
Analysis of variance (ANOVA) is a method on collecting all data and applying on the statistical models. ANOVA is used to analyze the divergence between the group means and their related procedures. In the recent past decades, statistical approaches have been widely applied to corrosion problems. Many authors have investigated the statistical significance by using F- test. Rajendran and his team studied the inhibitive effect of Phyllanthus amarus extract- $\mathrm{Zn}^{2+}{ }^{92}$ and Henna leaves extract- $\mathrm{Zn}^{2+}{ }^{93}$ on carbon steel by weight loss and electrochemical methods and proved that the given system was statistically significant. Yaro and his co-workers ${ }^{94}$ have used ANOVA on the data for the corrosion prevention of MS in $1 \mathrm{M}$ phosphoric acid by apricot juice obtained from weight loss data. ANOVA has shown that the corrosion rate is influenced by temperature, inhibitor concentration and combined interaction of them. Loto and his co-workers ${ }^{95}$ studied the inhibition performance of Vernonia amygdalina extract on the MS corrosion 1 in neutral medium. The outcome of the statistical test verified with the results at $95 \%$ of assurance. Similarly another author investigated the performance of fenugreek (Trigonella foenum graecum) ${ }^{96}$ seed extract as an inhibitor on mild steel under corrosive medium. A statistical view on their investigations revealed that the synergistic effect existing between fenugreek extract and potassium iodide is statistically significant.

The computational approach is useful to correlate the adsorption of molecules over the metal surface and the extent of protection by applying the computer modeling techniques. This approach needs an understanding the mathematics which governs the corrosion process and the physical phenomenon of corrosion. Many attempts were made by many researchers and they correlate the properties of the molecule with their respective structures of isolated molecules and in turns their inhibition by performing calculations by DFT under specific conditions. However, the leaves extract of Salvia officinalis ${ }^{97}$ were used as a stainless steel corrosion inhibitor for in $1 \mathrm{M} \mathrm{HCl}$ solution by means of mass loss and electrochemical experiments. Bothiraja and his team ${ }^{98}$ isolated pure alkaloid ( $3 \beta$-isodihydrocadambine) from Neolamarckia cadamba and investigated it for mild steel corrosion in $1 \mathrm{M} \mathrm{HCl}$ medium. They gave evidence of the adsorption by molecular modeling and proved that the shielding effect was caused by alkaloids particularly, $3 \beta$-isodihydrocadambine. Egbedi and his co workers ${ }^{99}$ studied the correlation between the inhibitive effect and electronic properties of Spondias mombin extract and its major constituents using density functional theory. Jyothi and Rathidevi ${ }^{100}$ explained the corrosion inhibition of mild steel in the sulphuric acid medium by Coccinia indica leaves extract using mass loss and electrochemical experiments. The adsorption of the inhibitor on mild steel surface is spontaneous is confirmed by thermodynamic parameters. The adsorption of the inhibitor on metal surface obeyed Langmuir adsorption isotherm. It was believed that the FTIR and optical profiler images confirmed the adsorption of the inhibitor. Simulation confirmed adsorption of the constituents on the metal surface and thereby protecting the surface from corrosion.

\section{CONCLUSION}

The industrial and technological development tends to the use of many metals for construction and fabrication. Because of the improper maintenances, the metal of choice leads to a severe attack, resulting in awful degradation. Although many research articles are witnessing that the current exhaustive research being performed to undertake to identify the issues on metallic corrosion in various environments. In spite of these disadvantages mentioned, this article has shown that the usage of such eco-friendly corrosion inhibitors is the only way onward in the search for safer and environmentally secure protection against metal corrosion.

\section{ACKNOWLEDGMENT}

The authors wish to acknowledge Kumaraguru College of technology, Coimbatore, India, for providing the necessary facilities to carry out the studies.

\section{REFERENCES}

1. B. Sanyal, Prog. Org. Coat., 9,165(1981), DOI: 10.1016/0033-0655(81)80009-X

2. P. B. Raja and M. G. Sethuraman, Mater. Letters, 62,113(2008), DOI: 10.1016/j.matlet.2007.04.079

3. B. E. Amitha Rani and J. B. Bharathi Bai, Int. J. Corros., 10, 1(2012), DOI: 10.1155/2012/380217

4. M. Bethencourt, F. J. Botana, J. J. Calvino, M. Marcos and M. A. Rodriguesz Chacon, Corr. Sci., 40, 1803 (1998), DOI: 10.1016/S0010-938X(98)00077-8

5. D. M. Abdullah, Indus Lub. Trib., 63, 227(2011). 
RASĀYAN J. Chem.

Vol. 12 | No. 2 |537 - 544| April - June | 2019

6. D. Kesavan, M. Gopiraman and N. Sulochana, Chem. Sci. Rev. Lett., 1, 1(2012).

7. N. Patni, S. Agarwal and P. Shah, Chin. J. Eng., 78, 6(2013), DOI: 10.1155/2013/784186

8. R.Rajilakshmi, A. Prithiba and S. Leelavathi, J. Chemica acta, 1, 6(2012).

9. M. Sangeetha, S. Rajendran, T. S. Muthumegala and A. Krishnaveni, Zaštita Materijala., 52, 173(2011).

10. B. E. Amitha Rani and Bharathi Bai J. Basu, Int. J. Corros., 217, 15(2012), DOI: $10.1155 / 2012 / 380217$

11. F.N. Speller, Corrosion Causes and Prevention, McGraw-Hill, New York, 1935.

12. H. Luo, Y.C. Guan and K.N. Han, Corrosion, 54, 721(1988), DOI: 10.5006/1.3284891

13. F. Bentiss, M. Traisnel and M. Lagrenee, Corros. Sci. 42, 127(2000), DOI: 10.1016/S0010938X(99)00049-9

14. M. Lagrenee, B. Mernari, N. Chaibi, M. Traisnel, H. Vezin and F. Bentiss, Corros. Sci., 43, 951(2001), DOI: $10.1016 / \mathrm{S} 0010-938 X(00)$ 00076-7

15. S.T. Arab and E.A. Noor, Corrosion, 49, 122(1993), DOI: $10.5006 / 1.3299206$

16. B.T. Kilbourn, Cer. Eng. Sci. Proc., 6, 1331(1985), DOI: 10.1002/9780470320297.ch16

17. M.A. Arenas, A. Conde and J. de Damborenea, Corros. Sci., 44, 511(2002), DOI: 10.1016/S0010938X(01)00053-1

18. M. Bethencourt, F.J. Botana, J.J. Calvino and M. Marcos, Corros. Sci., 40, 1803(1998), DOI: 10.1016/S0010-938X(98)00077-8

19. M. Sanaa, El-Sawy, M. Yosreya, A. Ayana, A. Fikry and A. Mohdy, Anticorros. Meth. Mat., 48, 227(2001), DOI: 10.1108/EUM0000000005630

20. E. Cano, P. Pinilla, J.L. Polo and J.M. Bastidas, Mater. Corros., 54, 222(2003), DOI: 10.1002/maco.200390050

21. G. Moretti, F. Guidi and G. Grion, Corros. Sci., 46, 387(2004), DOI: 10.1016/S0010938X(03)00150-1

22. D. J. Choi, Y. W. Kim and J. G. Kim, Mater. Corros., 52, 697(2001), DOI: 10.1002/15214176(200109)52:9<697::AID-MACO697>3.0.CO;2-5

23. J. Baldwin, British Patent, 2327 (1895).

24. N. Putilova, S.A. Balezin and V.P. Barannik, Metallic Corrosion Inhibitors, Pergamon Press, Oxford, London (1960).

25. A. A. El Hosary, R. M. Saleh and A. M. Shams El Din, Corros. Sci., 12, 897(1972), DOI: 10.1016/S0010-938X(72)80098-2

26. K. Srivatsava and B. Sanyal, Proc. Symposium of Cathodic Protection, Defence Research Laboratory, Kanpur, India (1973) 1.4.

27. B.C. Srivatsava and B. Sanyal, Proc. Symposium of Cathodic Protection, Defence Research Laboratory, Kanpur, India (1973) 1.2.

28. G. Cabrera, E. Ramos, J. Perez and J. Santhomas, Cuba Azucar (patent) 13 (1977).

29. K. Srivatsava and P. Srivatsava, Br. Corros. J., 16, 221(1981), DOI: 10.1179/000705981798274788

30. R. M. Saleh, A. A. Ismail and A. H. El-Hosary, Br. Corros. J., 17, 131 (1982)

31. F. Zucchi, I. H. Omar, Surf. Tech., 24, 391(1985), DOI: 10.1016/0376-4583(85)90057-3

32. S.J. Zakvi and G.N. Mehta, Trans. SAEST, 23, 4(1988).

33. A. Hussein and G. Singh., J. Electrochem. Soc.,40, 153(1991).

34. K. Pravinar, A. Hussein, G. Varkey and G. Singh, Trans. SAEST., 28 8(1993).

35. M.J. Sanghvi, S.K. Shukla, A.N. Mishra, M.R. Padh and G.N. Mehta, 5th National Congress on Corrosion Control, New Delhi, 46 (1995).

36. M.J. Sanghvi, S.K. Shukla, A.N. Mishra, M.R. Padh and G.N. Mehta, Trans. MFSI., 5143 (1996).

37. E. Ebenso, U.J.I. Bok and W. Afri, J. Biol. Appl. Chem., 37, 13(1994), DOI: 10.5006/1.3284811

38. U.J. Epke, E.E. Ebenso and U.J.I. Bok, J.W. Afr. Sci. Assoc., 37, 13(1994), DOI: 10.1080/14330237

39. A. Y. El-Etre and M. Abdallah, Corros. Sci., 42, 731(2000), DOI: 10.1016/S0010-938X(99)00106-7

40. A. Y. El-Etre, Corros. Sci., 40, 1845(1998), DOI: 10.1016/S0010-938X(98)00082-1

41. A. Minhaj, P.A. Saini, M. A. Quarishi and I. H. Farooqi, Corros. Prev. Control, 4632 (1999).

42. P. Kar, A. Hussein, G. Varkey, and G. Singh, Trans. MFAI, 51,143(1996). 
RASĀYAN J. Chem.

Vol. 12 | No. 2 |537 - 544| April - June | 2019

43. P. Sakthivel, P.V. Nirmala, S. Umamaheswari, A. Arul Antony, G.P.P. Kalignan, A. Gopalan and T. Vasudevan, Bull. Electrochem., 15, 83 (1999), DOI: 10.1007/BF01016223

44. S. Verma and G.N. Mehta, Trans. SAEST., 32, 4 (1997).

45. S. Verma and G.N. Mehta, Bull. Electrochem., 15, 67(1999), DOI: 10.1023/A:100346491

46. E. Khamis and N. Al-Andis, Mat.-wiss.u.werkstofftech, 33, 550(2002), DOI: 10.1002/15214052(200209)

47. B. Bouyanzer, B. Hammouti and L. Majadi, Mater. Lett., 60, 2840(2006), DOI: 10.1016/j.matlet.2006.01.103

48. A. Chetouani, B. Hammouti and M. Benkaddour, Pigm. Res. Techn., 33, 26(2004), DOI: $10.1108 / 03699420410512077$

49. A. Bouyanzer and B. Hammouti, Pigm. Res. Techn., 33, 287(2004), DOI: $10.1108 / 03699420410560489$

50. M. Benabdellah, B. Hammouti, M. Bendahhou and A. Aouniti, Appl. Surf. Sci., 252, 6212(2006), DOI: $10.1016 /$ j.apsusc. 2005.08 .030

51. N. Poongothai, N. Rajendran and M. Palaniswamy, Indian J. Chem. Tech., 12, 641(2005), DOI: 10.1016/j.nopr.niscair.2005.123456789/8684

52. E. Chaieb, A. Bouyanzer, B. Hammouti, M. Benkaddour and M. Berrabah, Trans. SAEST., 39, 58 (2004).

53. M. Bendahou, M. Benabdallah and B. Hammouti, Pigm. Res. Techn., 35, 95(2006), DOI: 10.1108/03699420610652386

54. A. Bouyanzer, L. Majidi and B. Hammouti, Bull. Electrochem., 22, 321 (2006).

55. O.Ouachikh, A. Bouyanzer, M. Bouklah, J-M. Desjobert, J. Costa, B. Hammouti and L. Majidi, Surf. Rev. Lett., 16, 49(2009), DOI: 10.1142/S0218625X09012287

56. B. Zerga, M. Sfaira, Z. Rais, M. Ebn Touhami, M.Taleb, B. Hammouti, B. Imelouane and A. Elbachiri, Materiaux et Technique, 97, 297(2009), DOI: 10.1051/mattech/2009045

57. N. Lahhit, A. Bouyanzer, J.M. Desjobert, B. Hammouti, R. Salghi, J. Costa, C. Jama, F. Bentiss and L.Majidi, Portugal. Electrochimi. Acta., 29, 57(2011), DOI: 10.4152 / pea.201102127

58. M. Znini, G. Cristofari, L. Majidi, A. Bouyanzer, J. Paolini, B. Hammouti and J. Costa, Int. J. Electrochem. Sci., 6, 6699(2011)

59. D. Ben Hmamou, R. Salghi, Lh. Bazzi, B. Hammouti, S.S. Al-Deyab, L. Bammou, L. Bazzi and A. Bouyanzer, Int. J. Electrochem. Sci., 7, 1303(2012), DOI: 10.1186/2228-5547-3-25

60. D. Ben Hmamou, R. Salghi, A. Zarrouk, B. Hammouti, S.S. Al-Deyab, Lh. Bazzi, H. Zarrok, A. Chakir and L. Bammou, Int. J. Electrochem.Sci., 7, 2361 (2012) .

61. F. Darriet, M. Znini, L. Majidi, A. Muselli, B. Hammouti and A. Bouyanzer, J. Costa, Int. J. Electrochem. Sci., 8, 4328(2013).

62. D. Ben Hmamou, R. Salghi, A. Zarrouk, H. Zarrok, M. Errami, B. Hammouti, L. Afia, Lh. Bazzi and L. Bazzi, Res. Chem. Intermed., 39, 973(2013).

63. R. Ananda Louise Sathiyanathan, S. Maruthamuthu, M. Selvanayagam, S. Mohanan and N. Palaniswamy, Ind. J. Chem. Tech., 12, 356(2005).

64. K.S. Parikh and K.J. Joshi, Trans. SAEST., 39, 29 (2004).

65. S.P. Ramesh, K.P. Vinod Kumar and M.G. Sethuraman, Bull. Electrochem., 17, 141(2001).

66. M.G. Sethuraman, P. Vadivel and K.P. Vinod Kumar, J. Electrochem. Soc. Ind., 50, 143(2001).

67. P. B. Raja and M.G. Sethuraman, Mater. Lett., 62, 2977(2008), DOI: 10.1016/j.matlet.2008.01.087

68. M. G. Sethuraman and P. B. Raja, Pigm. Res. Techno., 34, 327(2005), DOI: $10.1108 / 03699420510630345$

69. P. B. Raja and M.G. Sethuraman, Mater. Corros., 60, 22(2009), DOI: 10.1002/maco.200805027

70. E. E. Oguzie, Pigm. Res. Techno., 34, 321(2005), DOI: 10.1108/03699420510630336

71. E. E. Oguzie, Mater. Chem. Phys, 99, 441(2006), DOI: 10.1016/j.matchemphys.2005.11.018

72. L. R. Chauhan and G. Gunasekaran, Electrochimica Acta., 49, 4387(2004), DOI: 10.1016/j.electacta.2004.04.030

73. K. O. Orubite, P. C. Oforka, Mater.Lett., 58, 1768(2004), DOI: 10.1016/j.matlet.2003.11.030 
RASĀYAN J. Chem.

Vol. 12 | No. 2 |537 - 544| April - June | 2019

74. A. M. Abdel-Gaber, B. A. Abd-El-Nabey and M. Saadawy, Corr. Sci. 51, 1038(2009), DOI: 10.1016/j.corsci.2009.03.003

75. P. C. Oforka, M.E. Ikpi, I.E. Uwah, E. E. Ebenso, U. J. Ekpe and S.A.Umoren, Corr. Sci., 50, 2310(2008), DOI: 10.1016/j.corsci.2008.05.009

76. A. Y. El-Etre, Mater. Chem.Phys. 108, 278(2008), DOI: 10.1016/j.matchemphys.2007.09.037

77. N. O. Eddy, S. A. Odoemelam and A. O. Odiongenyi, J. Appl. Electrochem., 39, 849(2009), DOI: 10.1007/s10800-008-9731-z

78. U.M. Eduok , S. A. Umoren and A. P. Udoh, Arabian J. Chem., 9, S209(2016), DOI: 10.1016/j.arabjc.2011.03.008

79. D. Jalajaa,J. Mallika and S. Jyothi, Rasayan journal of chemistry, 10,1271(2017), DOI: 10.7324/RJC.2017.1041926

80. E.Akbarzadeh, M. N. Mohamad Ibrahim and A.A. Rahim, Int. J. Electrochem. Sci., 6, 5396(2011).

81. P.B. Raja, A.A. Rahim, H. Osman and K.Awang, Int. J. Min. Met. Mater., 18, 413(2011), DOI: 10.1007/s12613-011-0455-4

82. W.A.W. Elyn Amira, A.A. Rahim, H. Osman, K. Awang and P. Bothi Raja, Research J. Chem. Environ., 15, 519 (2011).

83. W.A.W. Elyn Amira, A.A. Rahim, H. Osman, K. Awang and P. Bothi Raja, , Int. J. Electrochemi. Sci., 6, 2998(2011).

84. A. A. Rahim, E. Rocca, J. Steinmetz and M. J. Kassim, Corros. Sci., 50, 1546(2008), DOI: 10.1016/j.corsci.2008.02.013

85. A. A. Rahim and J. Kassim, Recent Patents on Materials Science, 1, 223(2008).

86. S. Garai, S.Garai, P. Jaisankar, J.K. Singh and A. Elango, Corros. Sci., 60, 193(2012), DOI: 10.1016/j.corsci.2012.03.036

87. S. S. de Assuncao Araujo Pereira, M . M. Pegas, T. L. Fernandez, M. Magalhaes, T.G. Schontag, D. C. Lago, L.F. de Senna and E. D'Elia, Corros. Sci., 65, 360(2012), DOI: 10.1016/j.corsci.2012.08.038

88. T. Ibrahim, H. Alayan and Y. Al Mowaqet, Prog. Org. Coat., 75, 456(2012), DOI: 10.1016/j.porgcoat.2012.06.009

89. M. Behpour, S.M. Ghoreishi, M. Khayatkashani and N. Soltani, Mater. Chem. Phys., 131, 621 (2012), DOI: $10.1016 /$ j.matchemphys.2011.10.026

90. P. Bothi Raja, M. Fadaeinasab, A. K. Qureshi, A. A. Rahim, H. Osman, M. Litaudon and K. Awang, Ind. Eng. Chem. Res., 52, 10582(2013), DOI: 10.1021/ie401387s

91. C. Kamal and M.G. Sethuraman, Ind. Eng. Chem. Res., 51, 10399(2012), DOI: 10.1021/ie3010379

92. M. Sangeetha, S. Rajendran, J. Sathiyabama, A. Krishnaveni, P. Shanthy, N. Manimaran and B. Shyamaladevi, Port. Electrochim. Acta., 29, 8(2011), DOI: 10.4152/pea.201101009

93. S. Rajendran, M. agasta r.bama devi, B. Shyamala devi, K. Rajam and J. Jeyasundari, Mater. Prot., 50, 77 (2009).

94. A. S. Yaro, A.A. Khadom and R. K. Wael, Alexandria Eng. J., 52, 129(2013), DOI: 10.1016/j.aej.2012.11.001

95. C.A. Loto, O. O. Joseph, R.T. Loto and A.P.I. Popoola, Int. J. Electrochem. Sci., 8 11087(2013).

96. S. Harikrishna, A. Begum and K. Roy, Int. J. Chem.Tech. Research, 5, 1829, (2013).

97. N. Soltani , N.Tavakkoli, M. Khayatkashani , M. Reza Jalali and A. Mosavizade, Corros. Sci., 62, 122(2012), DOI: 10.1016/j.corsci.2012.05.003

98. P. B. Raja, A. K. Qureshi, A. A. Rahim, H. Osman and K. Awang, Corros. Sci., 69, 292(2013), DOI: 10.1016/j.corsci.2012.11.042

99. N.O. Obi-Egbedi, I.B. Obot and S.A. Umoren, Arabian J. Chem, 5, 361(2012), DOI: 10.1016/j.arabjc.2010.09.002

100. S. Jyothi and K. Rathidevi, Rasayan journal of chemistry, 10,1253(2017), DOI: 10.7324/RJC.2017.1041924

[RJC-5000/2018] 